\title{
Bacterial communities in temperate and polar coastal sands are seasonally stable
}

\author{
Sebastian Miksch ${ }^{1}$, Mirja Meiners ${ }^{1}$, Anke Meyerdierks ${ }^{1}$, David Probandt ${ }^{1}$, Gunter Wegener (iD) ${ }^{1,2,3}$, Jürgen Titschack (iD ${ }^{2,4}$, \\ Maria A. Jensen (D) ${ }^{5}$, Andreas Ellrott $\mathbb{D}^{1}$, Rudolf Amann (iD ${ }^{1}$ and Katrin Knittel ${ }^{1 凶}$
}

(c) The Author(s) 2021

Coastal sands are biocatalytic filters for dissolved and particulate organic matter of marine and terrestrial origin, thus, acting as centers of organic matter transformation. At high temporal resolution, we accessed the variability of benthic bacterial communities over two annual cycles at Helgoland (North Sea), and compared it with seasonality of communities in Isfjorden (Svalbard, $78^{\circ} \mathrm{N}$ ) sediments, where primary production does not occur during winter. Benthic community structure remained stable in both, temperate and polar sediments on the level of cell counts and 16S rRNA-based taxonomy. Actinobacteriota of uncultured Actinomarinales and Microtrichales were a major group, with $8 \pm 1 \%$ of total reads (Helgoland) and $31 \pm 6 \%$ (Svalbard). Their high activity (frequency of dividing cells 28\%) and in situ cell numbers of $>10 \%$ of total microbes in Svalbard sediments, suggest Actinomarinales and Microtrichales as key heterotrophs for carbon mineralization. Even though Helgoland and Svalbard sampling sites showed no phytodetritus-driven changes of the benthic bacterial community structure, they harbored significantly different communities $(p<0.0001, r=0.963)$. The temporal stability of benthic bacterial communities is in stark contrast to the dynamic succession typical of coastal waters, suggesting that pelagic and benthic bacterial communities respond to phytoplankton productivity very differently.

ISME Communications

; https://doi.org/10.1038/s43705-021-00028-w

\section{INTRODUCTION}

Sandy sediments cover approximately $70 \%$ of continental shelves [1]. These sediments are characterized by high permeability and advective transport by which bottom water is pumped through the pore space [2]. Thus, they work as expansive filter systems: suspended particles, algae, and bacteria are transported with the penetrating water into the sediment, where they become trapped in the pores [1, 3-5]. Simultaneously, electron acceptors and nutrients are provided to benthic microbial communities, strongly enhancing bentho-pelagic coupling [6]. Continental shelf areas are highly productive ecosystems, contributing $15-21 \%$ to global primary production [7]. In shallow areas, up to $50 \%$ of the pelagic primary production can reach the seafloor $[8,9]$. Active heterotrophic bacteria rapidly mineralize the settled phytodetritus as well as fresh organic matter derived from benthic primary production $[1,2,10]$, as demonstrated by high extracellular enzyme activities, bacterial carbon production, and organic matter mineralization [11-13].

Despite the close linkage of water column and sediments, major compositional differences in microbial communities are evident [14-16]. For example, SAR11, SAR86, and "Candidatus Actinomarina" are abundant members of bacterioplankton, but rare in sediments. Based on an analysis of 509 samples spanning the global surface oceans to the deep-sea floor, pelagic, and benthic communities share only $10 \%$ of bacterial types defined at $3 \%$ sequence similarity level [16]. Compositional differences between pelagic and benthic microbial communities are accompanied by differences in function [15, 17]. Patterns of enzyme activities differed and showed a more diversified enzyme spectrum in sediments.

In the water column, phytoplankton blooms in spring and summer induce changes in bacterioplankton community structure [18-20]. For example, in the southern North Sea, relative cell numbers of Polaribacter, Ulvibacter, and SAR92 increased by factors of 5-20, shortly after bloom events [19]. These community dynamics were recurrent, indicating a phytodetritus-driven seasonality [19-21]. Knowledge of seasonality of benthic microbes, in contrast, is sparse. Seasonal changes in organic matter mineralization, extracellular enzyme activities, and bacterial biomass production rates were mostly related to temperature and substrate availability in sediments [5, 11, 22-24]. Different substrate additions showed specific effects on benthic microbial communities in incubations with Arctic deep-sea sediments Hausgarten, $78.5-80^{\circ} \mathrm{N}$ [25]. Addition of chitin resulted in an increased activity of the community without major compositional change, whereas addition of phytodetritus caused a strong change of community composition. Overall, there are only few studies of seasonal changes of microbial diversity and in situ abundance of major taxa [13, 26-29], indicating a high turnover of rare organisms but an unchanged pattern of major taxa [26]. In

\footnotetext{
${ }^{1}$ Max Planck Institute for Marine Microbiology, Bremen, Germany. ${ }^{2}$ MARUM, Center for Marine Environmental Sciences, University of Bremen, Bremen, Germany. ${ }^{3}$ Alfred Wegener Institute, Helmholtz Centre for Polar and Marine Research, Bremerhaven, Germany. ${ }^{4}$ Senckenberg am Meer, Wilhelmshaven, Germany. ${ }^{5}$ UNIS, The University Centre in Svalbard, Longyearbyen, Norway. ${ }^{凶}$ email: kknittel@mpi-bremen.de
}

Received: 11 May 2021 Revised: 13 May 2021 Accepted: 24 May 2021

Published online: 28 June 2021 
surface sediments from English Channel, Tait and colleagues found indications for seasonality of Flavobacteriia [29]. However, all these studies were based only on 2-5 sampling dates or on a single year.

In order to assess at high temporal resolution the variability of sandy sediment bacterial communities over an annual cycle, we sampled a shallow coastal site at Helgoland Roads (North Sea, $54^{\circ}$ N) 19 times over the course of two years. The sample intervals were 10-20 days apart, during the spring bloom, and 6-8 weeks for the rest of the year. Although phytoplankton at Helgoland exhibits a strong seasonality [30], metatranscriptomic analysis of sediments showed that $36-53 \%$ of mRNA transcripts were related to photosynthesis genes [31], indicating ongoing primary production either in the water column or in the sediments during winter. Therefore, in order to compare seasonality in sediments at a location where primary production does not occur during winter, we also visited Svalbard 6 times between December 2017 and September 2019. The Svalbard archipelago, at $76^{\circ}-81^{\circ} \mathrm{N}$, is sufficiently far North that primary productivity does not occur during the polar night [32].

We tested the hypothesis that phytodetrital input drives seasonal changes in benthic bacterial community structures of Svalbard and Helgoland sediments. In particular, we wanted to identify community changes typical of the strong seasonality found in higher latitudes. We expected changes to be more pronounced in Svalbard sediments than in Helgoland sediments. To quantitatively assess sedimentary communities, we initially established an automated microscopic system for enumeration of bacteria, and developed new probes for Actinobacteriota. The in situ abundances of major taxa were investigated by CARD-FISH and the bacterial diversity by $16 \mathrm{~S}$ rRNA gene sequencing.

\section{MATERIALS AND METHODS \\ Study sites and sampling}

At Helgoland, North Sea, (German Bight; $54.18^{\circ} \mathrm{N}, 7.90^{\circ} \mathrm{E}$ ), sediment samples were obtained by scientific divers of the Alfred Wegner Institute (Bremerhaven, Germany) using push cores. The sampling site is located at Helgoland Roads between the main island and the dune (Fig. 1A). Water depth varied between $\sim 3$ and $\sim 8 \mathrm{~m}$. At Isfjorden, Svalbard, Arctic Ocean (Fig. 1B), sediments were obtained using a van Veen grab deployed from R/V Farm. Stations were located near the coast and within $1 \mathrm{~km}$ distance to each other $\left(78.11^{\circ} \mathrm{N} 14.35^{\circ} \mathrm{E}\right.$, station $5 ; 78.10^{\circ} \mathrm{N} 14.38^{\circ} \mathrm{E}$, station $6 ; 78.10^{\circ} \mathrm{N}$ $14.38^{\circ} \mathrm{E}$, station $7 ; 78.10^{\circ} \mathrm{N} 14.39^{\circ} \mathrm{E}$, station 23$)$. Sampling dates were chosen according to light conditions: December 20th 2017 (24 h darkness), February 28th 2018 ( $7 \mathrm{~h}$ daylight), May 1st 2018 (24 h daylight), December 17th 2018 (24 h darkness), April 25th 2019 (24 h daylight), and September 13th 2019 ( $15 \mathrm{~h}$ daylight). Water depths varied between 3 and $9 \mathrm{~m}$. (sample processing: Supplementary Information; all data: Supplementary Table S1).

\section{Sediment particle-size measurements}

Particle-size measurements were performed in the Particle-Size Laboratory at MARUM, University of Bremen (Germany), with a Beckman Coulter Laser Diffraction Particle Size Analyzer LS 13320 (Beckman Coulter, Krefeld, Germany) following in principle the methodology of Boehnert et al. [33] (For details see Supplementary Information).

\section{Determination of carbon and nitrogen concentrations}

Freeze-dried sediments were grounded to a powder in a Planetary Micro Mill (Pulverisette 7, Fritsch, Idar-Oberstein, Germany). To determine total carbon and nitrogen, $\sim 25-50 \mathrm{mg}$ of sediment powder was packed in $5 \times 9 \mathrm{~mm}$ tin capsules (HEKAtech, Wegberg Germany). To determine organic carbon, inorganic carbon was removed with $1 \mathrm{M} \mathrm{HCl}$ before analysis. Samples were analyzed in an Euro EA-CNS elemental analyzer (HEKAtech, column temperature $75^{\circ} \mathrm{C}$; carrier gas helium at $80 \mathrm{ml} \mathrm{min}^{-1}$, reactor temperature $1000^{\circ} \mathrm{C}$ with oxygen flow $10 \mathrm{ml} \mathrm{min}{ }^{-1}$, oxidation time $7.9 \mathrm{~s}$ ) with thermal conductivity detection. Calibration was done with sulfanilamide $(0.2-2 \mathrm{mg})$ standards. The quantification limit for carbon and nitrogen was $0.2 \mathrm{mg}$ per gram sediment. In Helgoland samples, organic nitrogen concentrations were below quantification limit, hence values were not reported.
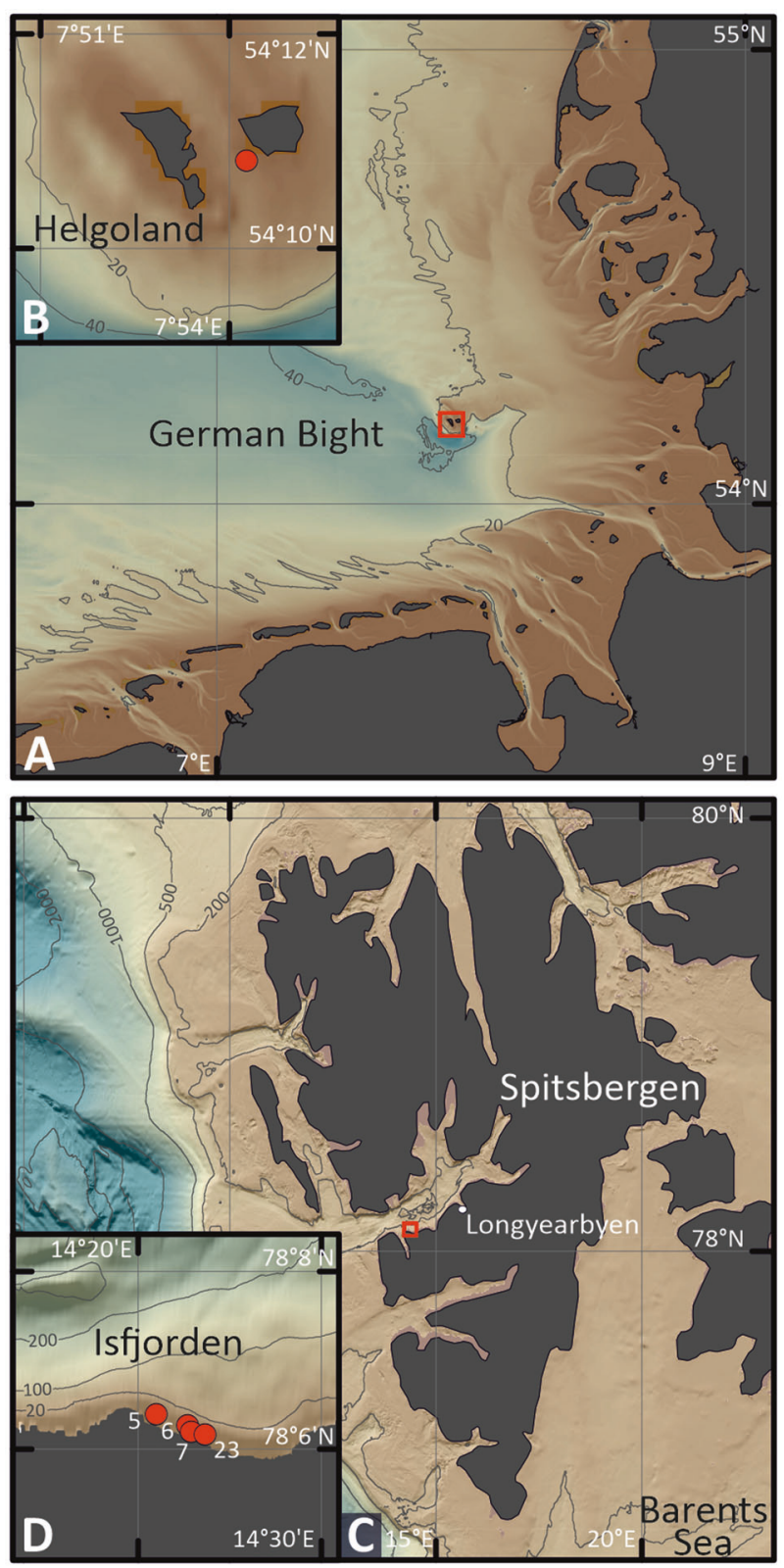

Fig. 1 Map of sampling areas. A, B Helgoland Roads, North Sea (German Bight); C, D Isfjorden, an Arctic fjord in western Spitsbergen (archipelago of Svalbard, Arctic Ocean). Data sources: European Environment Agency, EEA coastline derived from EU-Hydro and GSHHG data; http://www.eea.europa.eu/data-and-maps/data/eeacoastline-for-analysis and EMODnet Bathymetry Consortium (2016, 2020): EMODnet Digital Bathymetry (DTM). https://doi.org/10.12770/ bb6a87dd-e579-4036-abe1-e649cea9881a; https://doi.org/10.12770/ c7b53704-999d-4721-b1a3-04ec60c87238.

\section{Chlorophyll and phaeopigment measurements}

Pigments were yielded by extraction from $1 \mathrm{ml}$ sediment with $8 \mathrm{ml}$ acetone and disruption in a cell mill. The supernatant was collected after centrifugation and the extraction of the sediment was repeated twice. Two milliliter aliquots of the pooled extracts were subjected to fluorescence measurements [34] using a Trilogy Laboratory Fluorometer (Turner Designs; excitation $=428 \mathrm{~nm}$; emission $=671 \mathrm{~nm}$ ) and measured before and after acidification with $100 \mu \mathrm{l} 20 \% \mathrm{HCl}$. The concentration of chlorophyll $a(\mathrm{Chl} a)$, and phaeopigments (PhP) were determined according to

$$
\begin{aligned}
& \mathrm{Chla}[\mu \mathrm{g}]=\left(\mathrm{RFU}_{\mathrm{b}}-\mathrm{RFU}_{\mathrm{a}}\right) \times C F \times A F \times f \\
& \operatorname{PhP}[\mu g]=\left(\mathrm{RFU}_{a} \times \mathrm{AR}-\mathrm{RFU}_{\mathrm{b}}\right) \times C F \times A F
\end{aligned}
$$


with the relative fluorescence units before acidification $\left(\mathrm{RFU}_{\mathrm{b}}\right)$ and after acidification ( $\left.\mathrm{RFU}_{\mathrm{a}}\right)$ and the calibration factor (CF) and the dilution factor $(f)$ determined from chlorophyll standards as described by Lorenzen [34].

DNA extraction, amplification of 16S rRNA genes, sequencing DNA was extracted from sediment samples $(0-2 \mathrm{~cm}$ depth) according to Zhou et al. [35], slightly modified by adding three initial freeze-thaw cycles. DNA from surface seawater was extracted using DNeasy Power Water Kit (QIAGEN, Hilden, Germany). Amplification of 16S rRNA gene fragments was done using primers S-D-Bact-0341-b-S-17 and S-D-Bact-0785-a-A-21 [36]. Amplicons were sequenced on an Illumina (San Diego, CA, USA) platform (HiSeq2500, $2 \times 250$ bases, paired-end) at the Max Planck-Genome Center in Cologne (Germany). Sequences were processed using BBTools version 37.62 [ref. 37], mothur v.1.38.1 [ref. 38] and classified using the SILVAngs pipeline and database SSU 138.1 Ref NR99 [ref. 39] (details: Supplementary information).

\section{Amplicon sequence variants (ASV) analysis}

Demultiplexing and per sample extraction of forward and reverse fasto files was conducted using mothur v.1.39.5 ref. [38] and BBTools v. 37.90 ref. [37] ASVs were determined using dada2 v. 1.16 .0 ref. [40] (standard pooled processing; SSU 138 Ref NR99). All ASV taxonomically classified as "Chloroplast", "Archaea" or "Eukarya" as well as absolute singletons were removed from the dataset.

Alpha diversity was calculated using the subsamplingNGS.R function (https://github.com/chassenr/NGS/blob/master/Plotting/SubsampleNGS.R; 100 iterations) (For details see Supplementary information).

\section{Statistical analysis}

Statistical tests were performed using the R package vegan [41-43] and customized R-scripts. ANOSIM analyses [44] were performed with 999 permutations at equal group size treatment.

\section{Separation of cells from sediment grains}

Formaldehyde-fixed Svalbard sediment samples (for details see Supplementary Information) were sonicated on ice with a type MS2.5 probe (Sonoplus mini20; Bandelin, Berlin, Germany). Six sonication steps were done at a setting of $30 \mathrm{~s}$, an amplitude of $86 \%$ and pulse of $0.2 \mathrm{~s}$. Combined supernatants were filtered onto $0.2 \mu \mathrm{m}$ pore size polycarbonate filters (GTTP, Millipore, Eschborn, Germany). More than $90 \%$ of all cells have been separated from the sand grains without obvious cell damage (Supplementary Fig. S1). Silty sediments of station 6 and 23 (September 2019) were sonicated only once, diluted and directly filtered.

\section{Catalyzed reporter deposition fluorescence in situ hybridization (CARD-FISH)}

In situ hybridizations with horseradish peroxidase (HRP)-labeled probes followed by fluorescently-labeled-tyramide signal amplification were carried out as described previously [45], with few modifications. Inactivation of endogenous peroxidases was done by hydrogen peroxide $(0.15 \%$ in methanol) for $30 \mathrm{~min}$ at room temperature. Hybridization was performed at $46^{\circ} \mathrm{C}$ for $2-3 \mathrm{~h}$ in a chamber equilibrated with $2.25 \mathrm{M} \mathrm{NaCl}$ and identical formamide concentration as in the hybridization buffer. Amplification with Alexa 488-labeled tyramides was performed for $45 \mathrm{~min}$ at $46^{\circ} \mathrm{C}$. Filter sections were mounted with a mixture of CitiFluorAF1 (CitiFluor Ltd., London, United Kingdom] and Vectashield (Vector Laboratories, Burlingame, CA, USA) containing $1 \mu \mathrm{g} \mathrm{ml}^{-1}$ DAPI $\left(4^{\prime}, 6-\right.$ diamidino-2-phenylindole; Sigma-Aldrich, Steinheim, Germany). Probe sequences, permeabilization conditions and formamide concentrations are given in Supplementary Table S2.

\section{Automated imaging and counting}

For cell counting of bacteria in Svalbard sediments, we improved an automated system that was established for bacterioplankton [46, 47]. Low signal to background ratios in sediments compared to seawater required the use of narrow band pass optical filter sets. Number of layers for the imaged $z$-stack was increased to 13 (distance $0.4 \mu \mathrm{m}$ ). Filter sections were imaged by microscopy using a motorized epifluorescence microscope (Axiolmager. Z2m, Carl Zeiss, Jena, Germany) equipped with a 63x/1.4 Plan-Apochromat objective and controlled via the MPISYS software. Illumination was done using a Zeiss Colibri 7 LED source ( $385 \mathrm{~nm}$ for DAPI; $469 \mathrm{~nm}$ for Alexa488) using specific narrow band pass optical filter sets for DAPI (splitter $375 \mathrm{~nm}$; emission filter 448/20 nm) and Alexa488 (splitter $495 \mathrm{~nm}$; emission filter 520/ $15 \mathrm{~nm}$ ). The images were analyzed using the Automated Cell Measuring and Enumeration tool 3.0 (ACMEtool) software (M. Zeder, www.technobiology.ch. [47]). (For technical details see Supplementary Information).

\section{Probe design}

Probe design for Actinobacteriota based on SILVA database SSU 132 Ref NR99 and was performed with the probe design tool implemented in ARB [48] (Supplementary Fig. S2). CARD-FISH with a mix of probes ACM1218 (AGCATGCGTGCAGCCCTG; Actinomarinales) and MIT1218 (AGCATGTTTGCAGCCCTG; Microtrichales) resulted in counts that were equal to the sum of individual counts $(92 \pm 9 \%)$ confirming high probe specificity. An

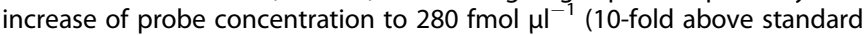
conditions) resulted in brighter signals and higher cell numbers (1-3-fold increase for ACM1218; 2-6-fold increase for MIT1218).

\section{Actinobacteriota imaging, cell size, and cell division}

Actinobacteriota were imaged by a laser scanning microscope (LSM780, Zeiss, Jena, Germany) equipped with an Airyscan detector. For cell size measurements, FISH [49] with Alexa594-tetralabelled probes and CARDFISH hybridization buffer was used to avoid an overestimation of cell sizes by too bright CARD-FISH signals.

The fraction of dividing cells was determined based on line profiles of DAPI and FISH signal fluorescence in formaldehyde-fixed Actinomarinales cells (Supplementary Fig. S3). Dividing cells were defined by two criteria: i) two DAPI maxima are visible in a single cell and ii) one or no FISH signal maximum is present in the cell center between the two DAPI maxima. If two FISH signal maxima were detected in the cell center, cell division was categorized as completed.

\section{RESULTS}

\section{Grain size}

Helgoland surface sediments were, in general, composed of fine and medium sand with variable portions of coarse to very coarse sand (Fig. 2A). Winter and early spring sediments contained a large portion of coarse to very coarse sand. Svalbard sediments of Isfjorden were mainly composed of very fine and fine sand with a small fraction of medium sand. Grain size distribution did not differ markedly across stations and seasons (Fig. 2B). Except for station 7 , grain size distribution changed in September 2019. Sediments from station 5 contained a minor portion of silt in addition to fine sand and medium sand. Composition of stations 6 and 23 sediments was shifted towards silty sand (station 6) and sandy silt (station 23).

\section{Organic carbon and nitrogen contents}

In Helgoland sediments, total organic carbon (TOC) content varied between $0.1 \%$ and $0.7 \%$ of sediment dry weight in 2018 (Fig. 3A). In 2019 , TOC was constantly low $(<0.13 \%)$. These TOC contents were typical for surface sediments of the Southern North Sea $(<0.1 \mathrm{mg}$ to $10 \mathrm{mg} \mathrm{g}^{-1}$, see ref. [50]) In Svalbard sediments, TOC content was between $0.2 \%$ and $0.5 \%$ in the winter, twilight, and spring samples (mean 0.3 $\pm 0.1 \%$; Fig. 3B). In September 2019, TOC in silty sediments from station 6 and 23 was highest with 0.7 and $0.9 \%$.

Organic nitrogen content in Svalbard sandy sediments was relatively stable (Supplementary Fig. S4), with quantities between 0.03 to $0.08 \%$ of sediment dry weight for all seasons. Total organic carbon/organic nitrogen (TOC/ $N_{\text {org }}$ ) ratios were $9.8 \pm 0.9$. Organic nitrogen contents of $0.08 \pm 0.01 \%$ were detected in silty sediments from stations 6 and 23 in September 2019. TOC/ $N_{\text {org }}$ ratio was $11.2 \pm 0.4$. TOC, $N_{\text {org }}$, and TOC $/ N_{\text {org }}$ ratios changed with grain size. In silty sands TOC was $0.8 \pm 0.1 \%, N_{\text {org }} 0.1 \pm 0.01 \%$ and a TOC $/ N_{\text {org }}$ ratio of $11.1 \pm 0.4$, while sandy sediments had a significantly lower TOC of $0.3 \pm 0.08 \%$, lower $N_{\text {org }}$ of $0.04 \pm 0.01 \%$ and a slightly lower $\mathrm{TOC} / \mathrm{N}_{\text {org }}$ ratio of $9.8 \pm 0.9$.

\section{Chlorophyll a concentrations}

In Helgoland sediments, concentrations of chlorophyll a ranged

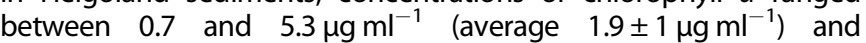


A Helgoland

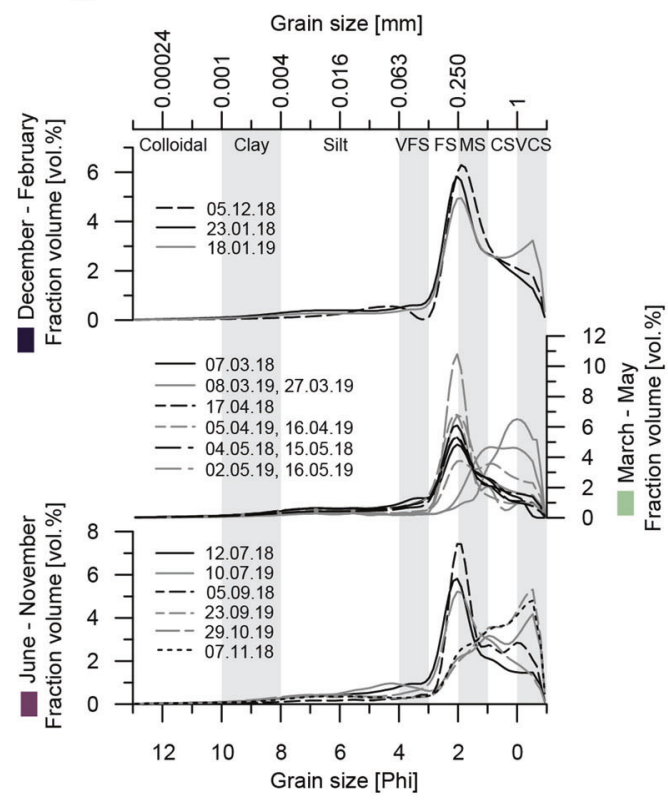

B Svalbard

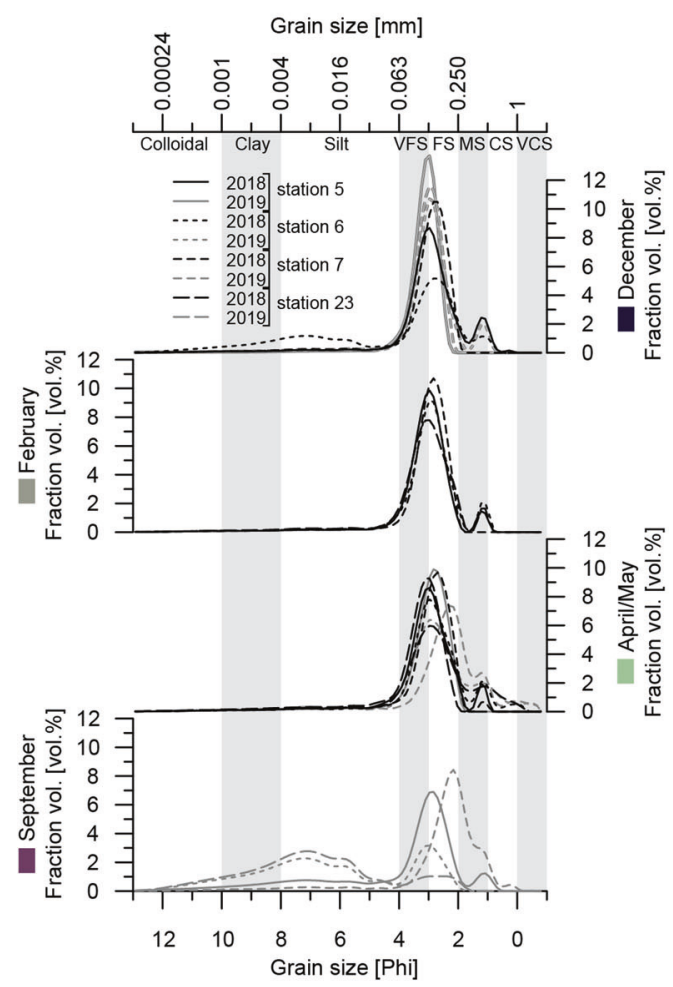

Fig. 2 Grain size distribution (vol\%) of A Helgoland and B Svalbard surface sediments $(0-2 \mathrm{~cm}$ depth) derived from laser diffraction particle size analysis. Please note the different $y$-scales for Helgoland samples.

concentrations of phaeopigments between 0.1 to $1.3 \mu \mathrm{g} \mathrm{ml}^{-1}$ (average $0.4 \pm 0.3 \mathrm{\mu g} \mathrm{ml}^{-1}$; Supplementary Table S1). On 4th of May 2018, we detected the strongest chlorophyll $a$ peak $(5.2 \mu \mathrm{g}$ $\mathrm{ml}^{-1}$ ) while concentration at all other time points were $2.6 \mu \mathrm{g} \mathrm{ml}^{-1}$ and lower. Nevertheless, no clear increase of chlorophyll concentrations in sediment samples from spring was observed.
In Svalbard sediments, chlorophyll $a$ concentrations were very low in winter and twilight samples $\left(0.3 \pm 0.1 \mathrm{\mu g} \mathrm{m}^{-1}\right.$ and $0.2 \pm 0.1$ $\left.\mu \mathrm{g} \mathrm{ml}^{-1}\right)$ and clearly higher in spring 2018 and summer/fall $(1.2 \pm$ $0.5 \mathrm{\mu g} \mathrm{m}^{-1}$ and $1.1 \pm 0.6 \mathrm{~g} \mathrm{ml}^{-1}$ ). In spring 2019, we measured only $0.3 \pm 0.1 \mu \mathrm{g}$ chlorophyll $a$ per $\mathrm{ml}$ of sediment. At the same time, however, chlorophyll $a$ concentrations in surface seawater were high by now $\left(7 \pm 1 \mu \mathrm{g} \mathrm{I}^{-1}\right)$ compared to winter $2018(0.4 \pm$ $0.02 \mathrm{\mu g} \mathrm{I}^{-1}$, Supplementary Table S1).

\section{Bacterial community composition}

The composition of bacterial communities of Helgoland and Svalbard surface sediments $(0-2 \mathrm{~cm}$ depth) and Svalbard surface seawater was investigated by $16 \mathrm{~S}$ rRNA gene sequencing. For simplicity, Helgoland sampling dates were assigned to meteorological seasons. Svalbard sampling dates were assigned to seasons based on light availability: winter (December 2017, 2018), twilight (February 2018), spring (April 2019, May 2018), and summer/fall (September 2019). Numerous 16S rRNA gene sequences from chloroplasts were detected in the dataset from both, Helgoland and Svalbard. In Svalbard sediments, they constituted $4 \pm 2,11 \pm 7,36 \pm 26$, and $31 \pm 11 \%$ of total reads and in surface seawater $1 \pm 0.2,3 \pm 0.3,80 \pm 10$, and $26 \pm 3 \%$ of total reads in winter, twilight, spring, and summer/fall, respectively. The strongly increased read frequency of chloroplast sequences in datasets of spring samples indicated the presence of a current or recent phytoplankton bloom. In Helgoland sediments portions of $16 \mathrm{~S}$ rRNA chloroplast sequences were low for all seasons. They constituted only $4 \pm 2,3 \pm 2$, and $4 \pm 2 \%$ of total reads during winter, spring, and summer/fall samples.

Helgoland sediments. The bacterial composition was stable for all 19 sampling dates (Fig. 4). The community was dominated by Gammaproteobacteria (winter: $35 \pm 2 \%$ of reads, spring: $34 \pm 4 \%$, summer/fall: $32 \pm 3 \%$ ). Within this class, Woeseia spp. dominated and did not change abundance (winter, spring, and summer/fall: $7 \pm 1 \%$ ). Further taxa with high read frequencies were Planctomycetota (winter: $8 \pm 0.4 \%$, spring: $7 \pm 1 \%$, summer/fall: $7 \pm 1 \%$ ), Alphaproteobacteria (winter: $11 \pm 2 \%$, spring: $10 \pm 3 \%$, summer/ fall: $12 \pm 3 \%$ ), Desulfobacterota (winter: $7 \pm 3 \%$, spring: $10 \pm 4 \%$, summer/fall: $9 \pm 4 \%$ ), and Bacteroidota (winter: $11 \pm 3 \%$, spring: $11 \pm 3 \%$, summer/fall: $14 \pm 2 \%)$.

Svalbard sediments. The bacterial community composition showed no clear changes between seasons (Fig. 4). Note that for calculation of mean read frequencies, data from silty sediments (station 6 and 23, September 2019) were excluded to avoid influence of reduced permeability and oxygen availability due to smaller grain size. Across all seasons, Actinobacteriota dominated the benthic community with $29 \pm 9 \%$ of reads (winter: $34 \pm 1 \%$, twilight: $26 \pm 1 \%$, spring: $31 \pm 8 \%$, summer/fall: $25 \pm 11 \%)$. These Actinobacteriota were mainly affiliated with uncultured Actinomarinales $(17 \pm 7 \%$ of reads; winter: $20 \pm 4 \%$, twilight: $17 \pm 2 \%$, spring: $18 \pm 6 \%$, summer/fall: $12 \pm 6 \%)$ and Microtrichales (12 $\pm 4 \%$ of reads; winter: $14 \pm 4 \%$, twilight: $8 \pm 2 \%$, spring: $13 \pm 3 \%$, summer/fall: $12 \pm 5 \%)$. Other abundant taxa were Bacteroidota (winter: $19 \pm 1 \%$ of reads, twilight: $18 \pm 2 \%$, spring: $18 \pm 3 \%$, summer/fall: $20 \pm 4 \%)$ with Maribacter being most dominant ( $4 \pm$ $2 \%$ ) and Planctomycetota (winter: $7 \pm 2 \%$, twilight: $9 \pm 2 \%$, spring: $6 \pm 2 \%$, summer/fall: $5 \pm 0.2 \%$ ). Stable read frequencies were also detected for diverse Proteobacteria: Gammaproteobacteria (winter: $11 \pm 1 \%$, twilight: $13 \pm 2 \%$, spring: $11 \pm 2 \%$, summer/fall: $8 \pm 1 \%$ ), Alphaproteobacteria (winter: $9 \pm 3 \%$, twilight: $8 \pm 1 \%$, spring: $10 \pm$ $3 \%$, summer/fall: $16 \pm 8 \%$ ), and Desulfobacterota (winter: $5 \pm 1 \%$, twilight: $7 \pm 1 \%$, spring: $4 \pm 1 \%$, summer/fall: $4 \pm 0.3 \%)$. ANOSIM statistics indicated that observed differences in read frequencies between seasons were not significant $(R=0.15, p=0.09)$.

In the two silty sediments (station 6 and 23, September 2019), communities were characterized by lower read frequencies of 

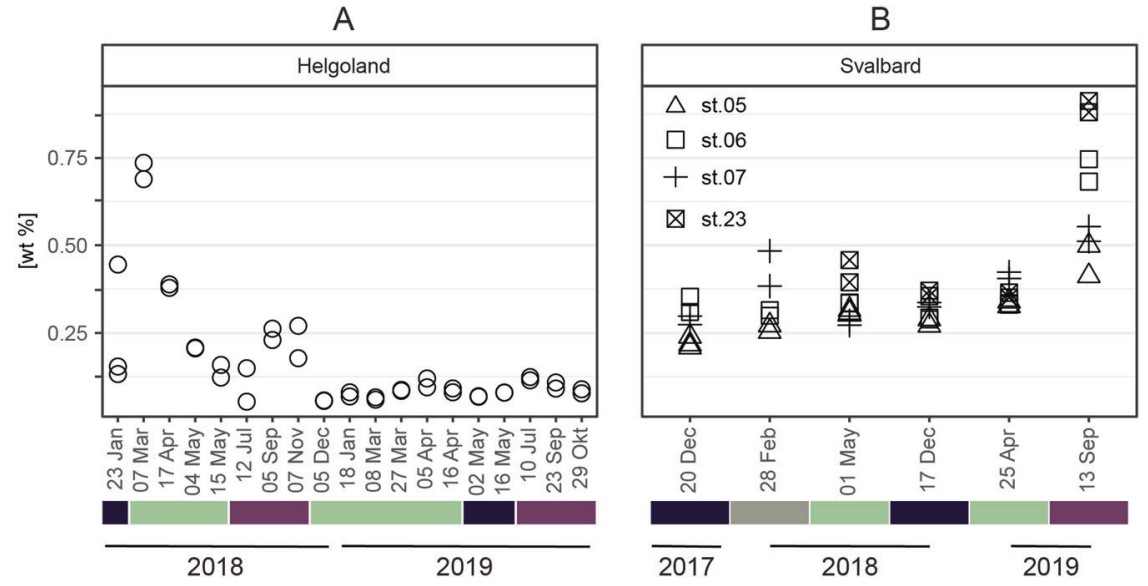

Fig. 3 Total organic carbon content in A Helgoland and B Svalbard sediments. Seasons are color-coded (winter: black, twilight: gray; spring: green; summer/autumn: aubergine-colored).

Actinobacteriota $(9 \pm 2 \%$ vs. $29 \pm 9 \%$ in sandy sediments) and Maribacter $(0.6 \pm 0.1 \%$ vs. $4 \pm 2 \%)$ and by higher frequencies of alphaproteobacterial Rhodobacteraceae $(20 \pm 1 \%$ vs. $8 \pm 5 \%)$. (Fig. 4). These changes were significant (Supplementary Fig. S5). Further significant changes were detected for less abundant genera of Bacteroidota, i.e., Maritimonas, Maribacter, Lutibacter, and Fluviicola.

Svalbard seawater. Bacterial communities in Svalbard surface seawater showed distinct seasonal patterns (Fig. 4). In winter, twilight and summer/fall, SAR1 1 dominated ( $53 \pm 13 \%$ of reads). In spring, SAR11 decreased to $23 \pm 8 \%$ while genus Polaribacter increased from $2 \pm 1$ to $31 \pm 12 \%$. Further taxa that strongly increased in spring 2019 were Nitrincolaceae (30 $\pm 4 \%$ vs. $1 \pm 1 \%$ across other seasons) and Colwelliaceae in spring 2018 (23 $\pm 5 \%$ vs. $0.1 \pm 0.2 \%)$.

Comparison of Svalbard and Helgoland sediment communities. Even though Helgoland and Svalbard benthic bacterial communities were seasonally stable, they harbored significantly different communities (ANOSIM; $p<0.0001, r=0.963$; Fig. 5). Read frequencies of Actinobacteriota, Maribacter, and Patescibacteria were much lower at Helgoland than at Svalbard (Actinobacteriota, $8 \pm 1 \%$ vs. $31 \pm 6 \%$ of reads; Maribacter, $0.7 \pm 0.2 \%$ vs. $5 \pm 2 \%$; Patescibacteria, $0.4 \pm 0.1 \%$ vs. $3 \pm 1 \%)$. In contrast, Acidobacteriota, were more abundant in Helgoland sediments $(3.5 \pm 0.4 \%$ vs. $0.6 \pm$ $0.1 \%)$. Different quantities and compositions of organic matter depending on the characteristics of the bloom as well as different grain size distributions might have caused the differences.

In situ quantification of major taxa in Svalbard sediments In situ quantification of major taxa focused on the region where we expected the most prominent seasonality, Svalbard. As a prerequisite, we modified the automated system developed for cell enumeration of bacterioplankton $[46,47]$. This system worked for both types of Svalbard sediments, sand and silt. Manual counts constituted $89 \pm 10 \%$ of automated counts (DAPI-stained cells), $112 \pm 26 \%$ (Desulobacterota/Myxococcota, probe DELTA495a-c) and $98 \pm 21 \%$ (Actinomarinales, probe ACM1218) (Supplementary Fig. S6). Although this system did not greatly reduce the time for sample processing compared with manual cell counting, it allows more standardized, thus more reliable, cell counting, and exclusion of human bias.

Total cell numbers varied between $1.2 \times 10^{8}$ and $1.3 \times 10^{9}$ cell $\mathrm{ml}^{-1}$ sediment (Supplementary Fig. S7). To normalize the differences in total cell counts, we focused on relative cell numbers to identify changes between seasons.
Overall, relative cell numbers of major taxa did not change significantly between winter and spring ( $t$-test: $p$-values between 0.260 and 0.842 ) (Fig. 6): Gammaproteobacteria (winter: $13 \pm 2 \%$, twilight: $13 \pm 2 \%$, spring: $13 \pm 3 \%$, summer/fall $12 \pm 2 \%$, Desulfobacterota/Myxococcota (winter: $11 \pm 3 \%$, twilight: $12 \pm 5 \%$, spring: $10 \pm 2 \%$, summer/fall $7 \pm 3 \%$ ), Planctomycetota (winter: $4 \pm 1 \%$, twilight: $4 \pm 2 \%$, spring: $3 \pm 2 \%$, summer/fall $4 \pm 0.1 \%$ ) and Verrucomicrobiota (winter: $2 \pm 0.3 \%$, twilight: $2 \pm 0.2 \%$, spring: 2 $\pm 0.2 \%$, summer/fall $3 \pm 0.6 \%$ ). Actinobacteriota of Actinomarinales and Microtrichales were found in high numbers, up to $10 \pm 2 \%$ of total cells across all seasons (Supplementary Fig. S7). Actinomarinales made up $5 \pm 1 \%$ of total cells (winter: $6 \pm 1 \%$, twilight: $5 \pm$ $1 \%$, spring: $6 \pm 1 \%$, summer/fall $5 \pm 2 \%$ ) and Microtrichales $4 \pm 1 \%$ (winter: $5 \pm 1 \%$, twilight: $5 \pm 1 \%$, spring: $5 \pm 1 \%$, summer/fall $4 \pm$ $0.3 \%)$.

Across seasons, the only striking change in relative cell numbers was detected for Bacteroidota, which increased by a factor of $\sim 2$ in summer/fall (winter: $7 \pm 2 \%$, twilight: $7 \pm 2 \%$, spring: $8 \pm 2 \%$, summer/fall $13 \pm 3 \%$ ). The change between winter and summer/ fall was significant ( $t$-test, $p=0.010$ ), however, we refrain from linking it to season because station 5 contained a minor part of silt besides fine sand, resulting in reduced permeability and oxygen availability (oxygen saturation in sediments from station 5 was lower than at station 7, data not shown). The influence of sediment-type on the bacterial community is even more pronounced in silty sediments of summer/fall where Bacteroidota increased to $15 \pm 1 \%$ of total cells. Our data support previous findings that permeability shapes the bacterial community $[51,52]$.

\section{Amplicon sequence variants and diversity parameters}

On the taxonomic level of genus and higher, Svalbard benthic bacterial communities did not show significant seasonal changes based on CARD-FISH cell numbers and read frequencies (Figs. 4 and 6). To address possible changes below genus level, we investigated seasonal changes of amplicon sequence variant (ASV) frequencies (Supplementary Table S3). In sediments, variations in frequencies of overall most abundant ASV between spring and winter were all within standard deviation (of the eight samples per category) indicating no significant change (Supplementary Fig. S8). Variations in frequencies of ASV from Gammaproteobacteria, Desulfobacterota, Bacteroidota, Verrucomicrobiota, and Actinobacteriota were also within standard deviation (Supplementary Fig. S9 and Supplementary Table S3). In contrast, frequencies of seawater ASV changed significantly and showed variations by factors of 6 and 1928 between spring and winter for the ten most abundant ASV. 


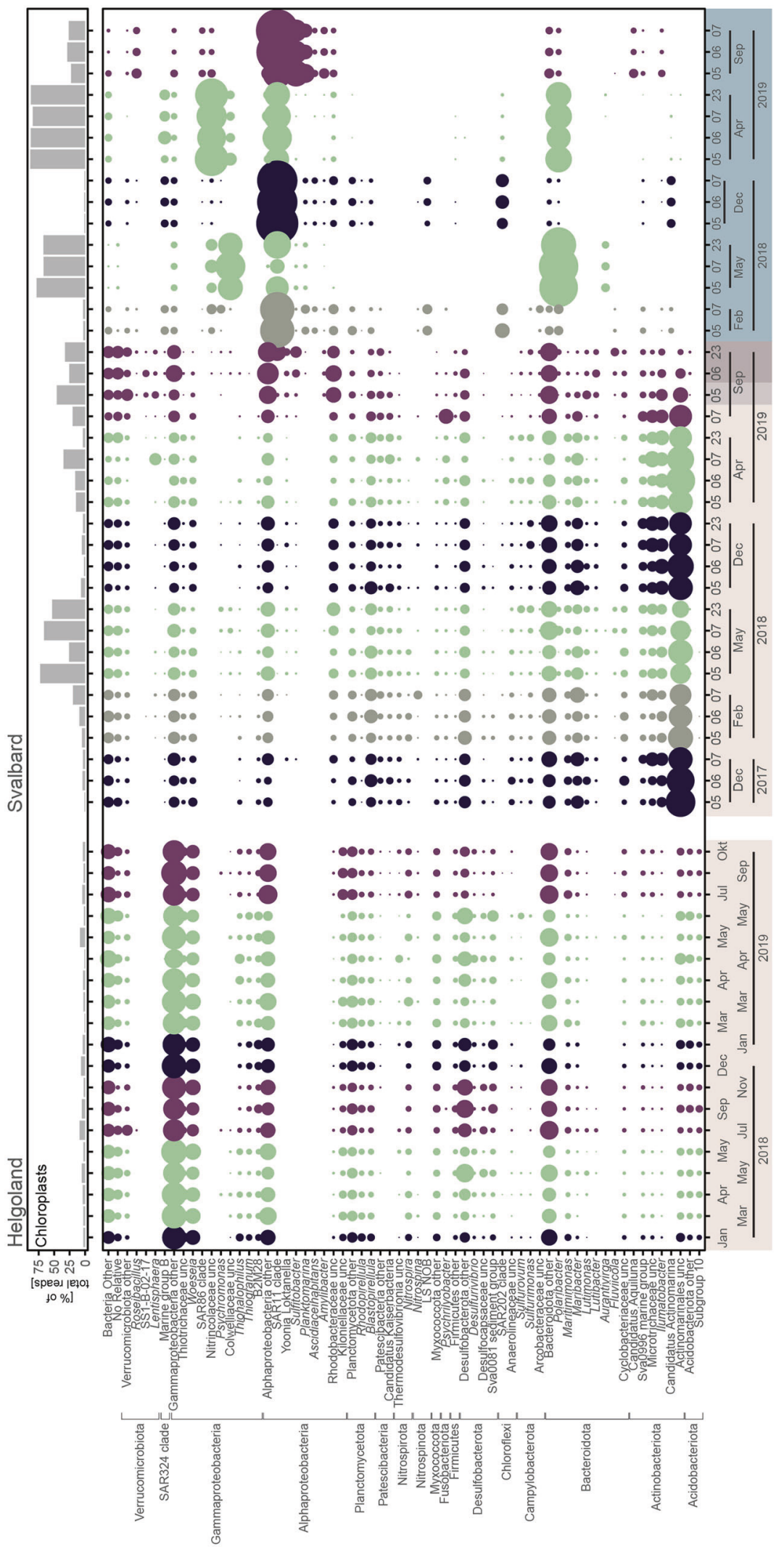

势

d

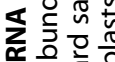

นัㅎำ

证记

t广

의

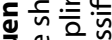

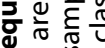

ธ。

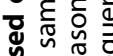

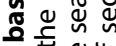

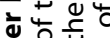

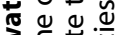

政

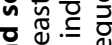

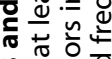

논.

ब

틍 눙흥

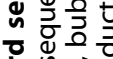

원.

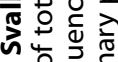

둥ㅇํㄹ

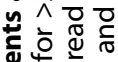

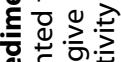

ơ

ปั

政

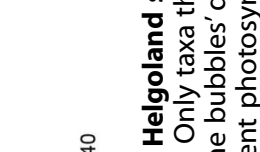

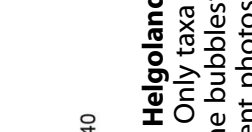

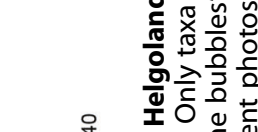

苛

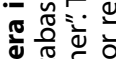

言 =

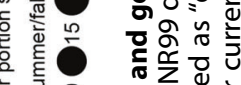

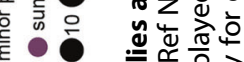

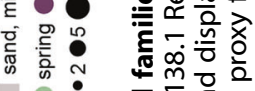

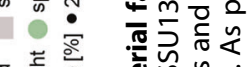

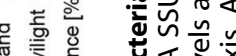

要

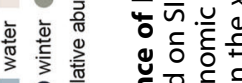

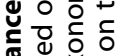

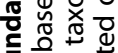

हैं 휴

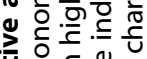

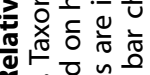

脑这 웡

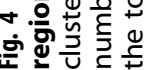




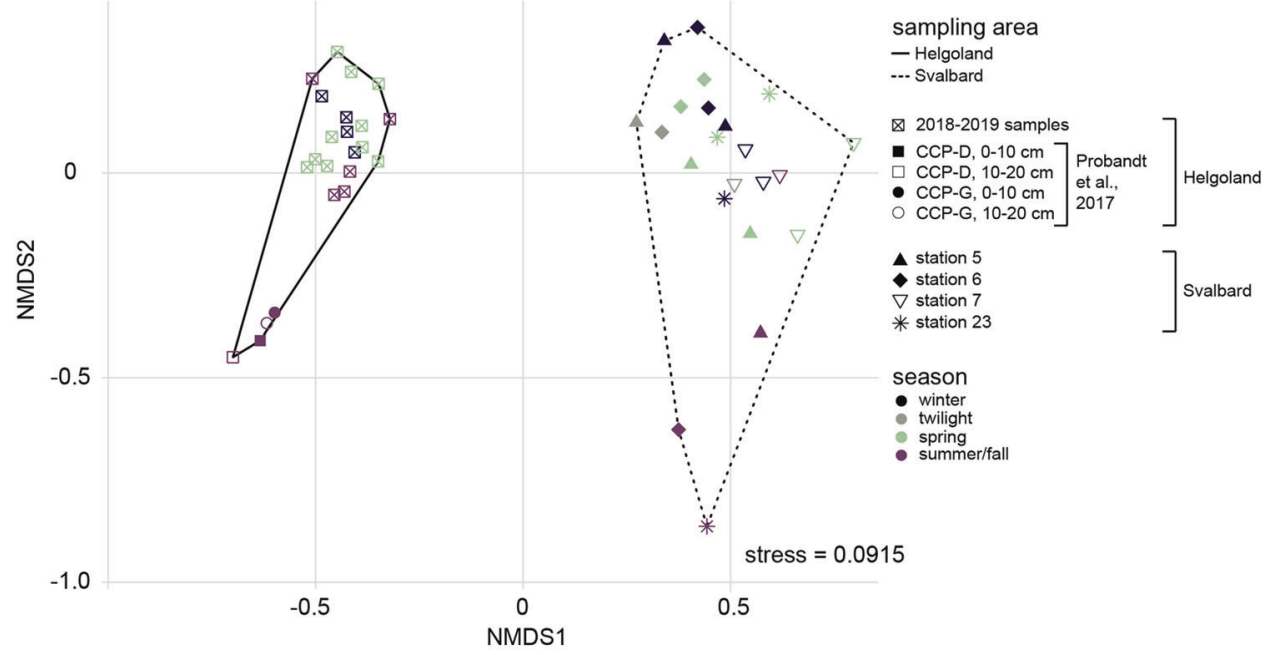

Fig. 5 NMDS ordination plot of sampling areas at Helgoland and Svalbard, generated from 16S rRNA gene datasets. Data from sites CCP$D$ and CCP-G, $6.5 \mathrm{~km}$ apart from Helgoland (bioproject number PRJEB18774, ref. [28]) were included in the analysis. The sampling areas are depicted as polygons. Helgoland and Svalbard bacterial community structures were significantly different supported by an ANOSIM $R$ value of $0.96(p<0.0001)$. Dissimilarity based on season was not supported by ANOSIM $(R=0.06, p=0.09)$.

Alpha diversity analysis as given by Inverse Simpson showed a lower diversity in Svalbard sediments from winter $(131 \pm 36)$ compared to spring (188 \pm 62$)$, however, the differences were still within standard deviation (Supplementary Table S4). In seawater, Inverse Simpson were higher in winter $(16 \pm 2)$ than in spring (12 \pm 5 ), mirroring the pelagic bacterial community dynamics detected by ASV frequencies.

\section{Actinobacteriota}

Actinobacteriota were the major phylum in Svalbard sediments based on cell numbers and read frequencies. The major part of Actinomarinales sequences was affiliated with clades Uncultured 1 and Uncultured 6 (Supplementary Fig. S2) that comprise sequences from diverse marine habitats (for example, Mediterranean beaches [53], Arctic sediments [54], polar waters [55], seafloor lavas [56]). Most abundant ASV\#473 (2.6\% of total reads) and ASV\#839 (1.8\%; Supplementary Table S3) were both affiliated with clade Uncultured 6 . Microtrichales sequences were mainly affiliated with Ilumatobacter, clade Sva0996, and clade Uncultured 10. Sva0996 was first found in Svalbard silty sediments from Hornsund [57]. Nowadays, Sva0996 comprises sequences from numerous marine habitats including beaches [53], permeable shelf sediments [58], tidal subsurface sediments [59], or seawater [60].

In situ detection revealed $\sim 95 \%$ of Actinomarinales were rods while $\sim 5 \%$ were cocci. Most cells were free-living, few cells occurred in loose biofilms (Fig. 7A). Microtrichales were also rodshaped (Fig. 7B), few cells were coccoid ( 10\%). Based on highresolution images, Actinomarinales were highly active as indicated by a frequency of dividing cells of $28 \%$ (station 6, December 2017; 78 cells analyzed; Supplementary Fig. S3). After division, Microtrichales and Actinomarinales cells had a size of approximately $0.25 \times 0.5 \mu \mathrm{m}$ and a volume of $0.024 \mu \mathrm{m}^{3}$.

\section{DISCUSSION}

Benthic bacterial communities are stable across seasons

A major part of the annual primary production in temperate and high latitude environments occurs during spring [30, 61-63]. Especially in the Arctic, the amounts and relative contributions of the different organic matter sources to fjords change seasonally and spatially [63-65]. Light is the limiting factor for phytoplankton growth during winter. In addition to light availability, runoff of suspended sediment from glaciers in summer and fall drives seasonality of organic matter input [66]. In Isfjorden, marine organic matter dominates in May following the spring phytoplankton bloom while in June and August, permafrost and glacialfed meltwater is present and a source of terrestrial organic matter [66]. Surface sediments at our sampling sites in Isfjorden are located in a wave-dominated embayment and are thus little affected by meltwater and river runoff (Rubensdotter and Jensen, 2020, map of Hollendarbukta stored at repository: https://svalcoast. $\mathrm{com} /$ ). This is also indicated by only a minor shift in $\mathrm{TOC} / \mathrm{N}_{\text {org }}$ between winter $(10.0 \pm 0.5)$ and spring $(9.5 \pm 1.0)$ and summer/fall $(10.8 \pm 0.5)$, although glacial meltwater runoff is probably the reason for more silty samples in September. In the bacterioplankton community, the seasonality in primary production at Svalbard was clearly causing compositional changes (Fig. 4 and Supplementary Fig. S8) such as a strong increase of Polaribacter and Aurantivirga, as previously seen also for Helgoland seawater $[18,19,21,67]$. However, the benthic bacterial communities at Svalbard and Helgoland, remained stable over two annual cycles. Cell numbers of major taxa and read frequencies of 165 rRNA genes on genus-level and below did not change significantly between winter and spring. Increased read frequencies of chloroplasts and chlorophyll concentrations in spring 2018 samples and summer/fall 2019 samples (Fig. 4 and Supplementary Table S1) indicated, that we did not miss the phytoplankton bloom or fresh organic matter from benthic primary production. Thus, the bacterial community might have responded to phytodetritus input by an increased activity rather than by changes in community structure. A response dominated by increased activity is supported by results of recent in situ experiments at Fram Strait, part of the Arctic deep-sea floor, where phytodetritus of either the diatom Thalassiosira sp. or the coccolithophore Emiliania huxleyi was provided to the benthic community. The community did not respond to the algal input by an increase of total bacterial cell numbers, but by an increase of exoenzymatic activities [68]. The high diversity of Svalbard benthic bacterial communities (observed number of ASV between 2526 and 6691) is coincident with a diverse spectrum of enzymes capable of degrading different substrates as previously suggested by Teske and colleagues [15]. Thus, responses to substrate input might preferentially be on the gene expression level rather than in community structure.

Although major taxa such as Actinomarinales were actively growing in Svalbard sediments, as shown by a high frequency of 

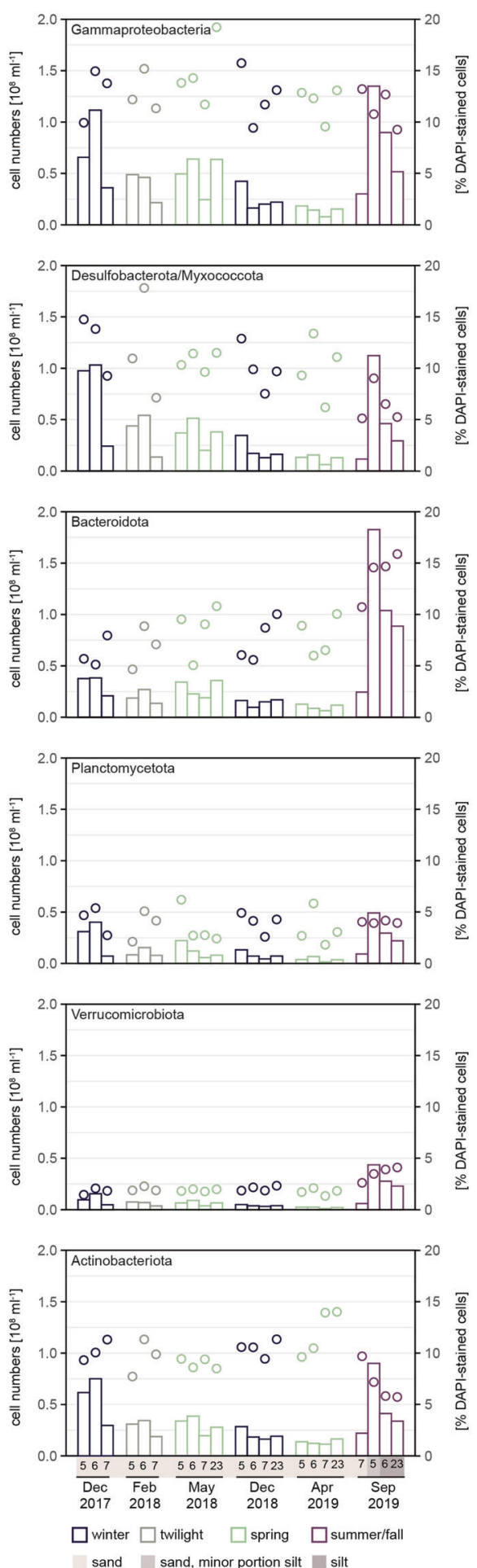

Fig. 6 In situ abundance of bacterial taxa in Svalbard sediments as determined by CARD FISH. Bars give absolute cells numbers, circles give relative abundances. Seasons are color-coded (winter: black, twilight: gray; spring: green; summer/fall: aubergine-colored).

dividing cells (28\%), we did not detect an increase in absolute cell numbers in any season. Bacterial biomass turnover time is short, typically within 2-18 days in organic-poor sands (average 5-6 days [11]). Grazing, however, is not considered the major process controlling the fate of bacterial biomass $[69,70]$. By an in situ pulse-chase experiment with ${ }^{13} \mathrm{C}$-tracers, van Oevelen and
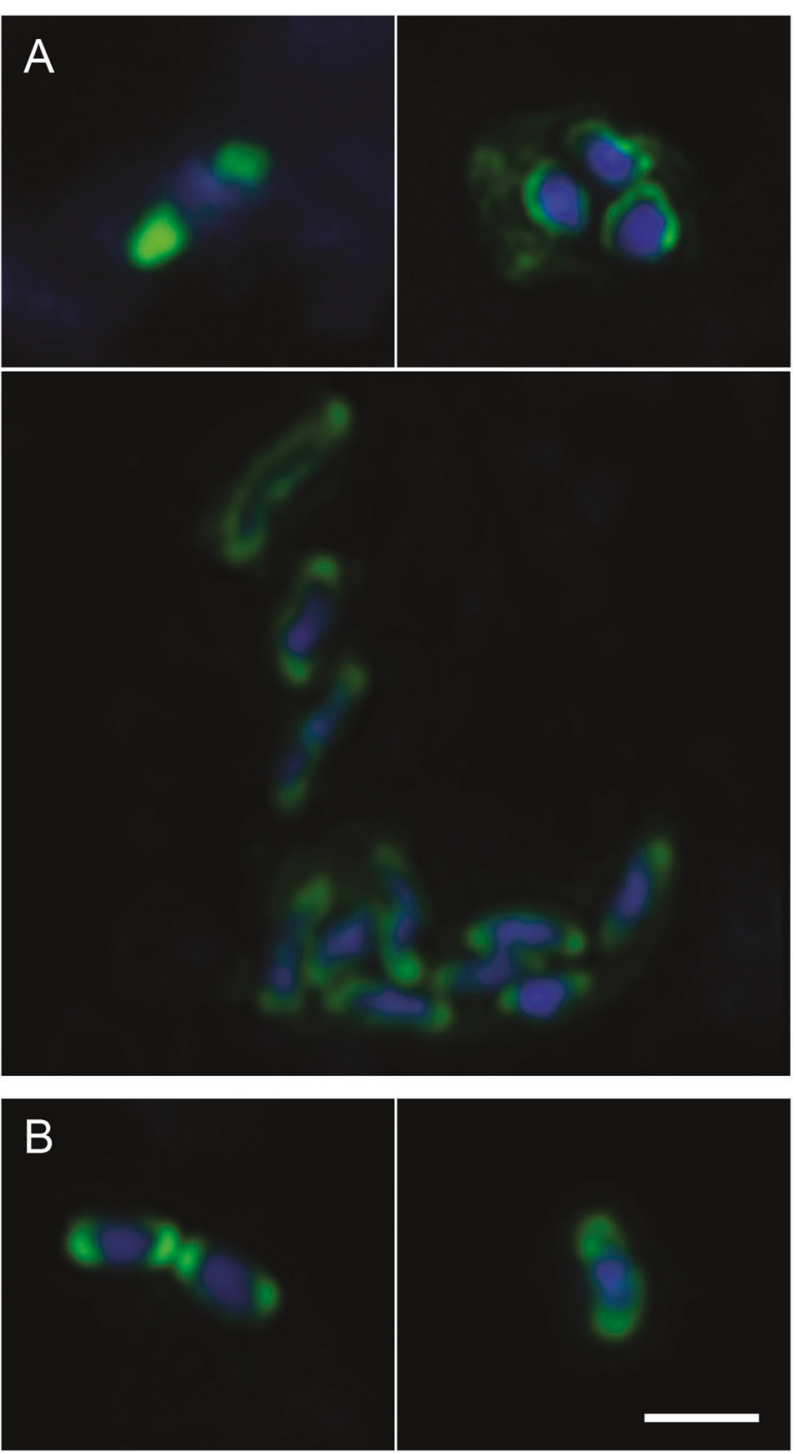

Fig. 7 Laser scanning micrographs of Actinobacteriota in Svalbard sediments as detected by CARD-FISH. A Actinomarinales visualized by probe ACM1218; B Microtrichales visualized by probe MIT1218. Green, CARD-FISH signals; blue, DAPI signals. Scale bar, $1 \mu \mathrm{m}$.

colleagues [70] quantified the fate of microphytobenthos in an estuarine tidal flat. They observed that grazing on bacteria by higher trophic levels is limited to $9 \%$ of total bacterial production. Virus-induced prokaryotic mortality account for $16 \pm 3 \%$ in coastal sediments $(n=11)$ [71].

In addition to loss via grazing and viruses, the seasonal stability of major taxa may well be linked to their physical growth conditions on sand grains. Life in cracks and depressions of the sand grain may protect microbes from grazing and abrasion when sand moves [72]. Microbes are neither evenly distributed nor do they form thick biofilms on sand grains: they colonize only about $4 \%$ of the grains' surface area [52, 73]. Non-populated, convex areas on the sand grains' surface could be too exposed to grazers and shearing forces during sediment reworking to maintain microbial populations. Large depressions might be diffusionlimited, reducing oxygen and nutrients supply to microbes [73]. Thus, our observations of i) active growth and ii) lack of seasonality of bacterial communities even after phytodetritusinput together with generally low population density on sand grains suggests a maximum of habitable surface area on a sand 
grain that keeps the bacterial community structure in a steadystate.

\section{Actinobacteriota are key heterotrophs in Svalbard sandy surface sediments}

Actinobacteriota of uncultured Actinomarinales and Microtrichales clades constituted the major taxon in Svalbard and Helgoland sandy surface sediments (Figs. 4 and 6). Taking into account the high read frequency of llumatobacter $(5 \%)$ and the missing coverage of this genus by the probes, the detected actinobacterial in situ abundance of $10 \%$ of total cells is likely still underestimated. Actinobacteriota constitute one of the most diverse bacterial phyla [74]. For decades, they were mostly viewed as soil bacteria, however, nowadays they are considered to be cosmopolitan in terrestrial and marine ecosystems [75]. Among marine bacterioplankton communities, Actinobacteriota are ubiquitous [76] and abundant (16S rRNA read frequencies 10\%) [77]. Pelagic and deep-sea benthic Actinobacteriota (16S rRNA read frequencies 4-31\%) [78] mainly belong to "Candidatus Actinomarina", also known as OM1 [79], which was only rarely detected $(<1 \%)$ in our datasets. In other Arctic surface sediments, actinobacterial sequences were either absent [15] or found in moderate $(5 \%$ refs. $[57,80])$ and high abundances (4-20\% of total reads [81]).

Studies on marine Actinobacteriota focused mainly on secondary metabolite production [82-84], thus their metabolism is largely unknown. In general, most Actinobacteriota are aerobic chemoheterotrophs using a wide variety of complex organic matter, including cell wall polysaccharides of plants such as cellulose, xylan, mannan, and other hemicelluloses, chitin or humic substances (for a review see ref. [85]). Actinobacteriota encode a huge diversity of carbohydrate-active enzymes. For example, fourteen glycoside hydrolases including GH3, GH18, GH36, GH65, and $\mathrm{GH} 92$ were found in the llumatobacter coccineum genome [86]. Based on the expression of a new kind of rhodopsin, a photoheterotrophic lifestyle was suggested for Candidatus Actinomarina [87]. Light, however, is not a key factor determining in situ abundance and activity of uncultured Actinomarinales in Svalbard sediments, as $28 \%$ were dividing in winter samples and cell numbers did not differ between seasons. Considering the high frequency of dividing actinobacterial cells and their high in situ cell numbers of at least $10 \%$ of total microbial community, uncultured Actinomarinales and Microtrichales likely play an important role in carbon mineralization in Svalbard sediments. Based on the carbohydrate-active enzymes typical of Actinobacteriota [85, 88, 89], we suggest that Actinomarinales and Microtrichales may be key heterotrophs hydrolyzing complex substrates.

\section{CONCLUSIONS AND OUTLOOK}

Pelagic and benthic microbial communities respond to phytoplankton productivity very differently. While the bacterial community of the water column dynamically responds to seasonal substrate input in cell numbers and composition, we observe stable benthic communities throughout two years of sampling. Thus, our hypothesis that substrate-based seasonality extends to benthic bacterial communities on the level of cell counts and $16 \mathrm{~S}$ rRNA-based taxonomy has been falsified for polar sediments from Svalbard as well as for temperate sediments from Helgoland.

Further studies must now target metagenomics and metatranscriptomics, metabolic activity, and gene regulation. For example, expression of glycoside hydrolases of GH16 (laminarinase) is expected to vary strongly between seasons, as the sugar polymer laminarin is a major storage compound in marine microalgae [90]. In contrast, animal-derived glycoproteins such as mucin are expected to be equally abundant throughout the year [91], and the respective degradative enzymes should be available during all seasons. The seasonal utilization of different substrates could be tested by applying fluorescently-labeled substrates [92], and this could be combined with identification of specific polysaccharide utilization loci and their expression [93].

Actinomarinales and Microtrichales should be target taxa in future studies. The likely absence of an outer membrane in these actinobacterial cells would not allow for polysaccharide degradation by selfish uptake, a major mode in the water column [94]. Previous studies showed relatively high extracellular polysaccharide hydrolysis rates of $\sim 0.5$ to $6 \mathrm{nmol}$ monomer $\mathrm{cm}^{-3} \mathrm{~h}^{-1}$ in Svalbard sediments $[95,96]$. Thus, we propose selfish uptake being of minor importance in sediments while degradation with exoenzymes dominates, releasing small substrates utilized by the plethora of microbial taxa living on sand grains.

\section{DATA AVAILABILITY}

Sequence data were stored in the European Nucleotide Archive (ENA) under study accession numbers PRJEB42060 and PRJEB42159. Other data from this study are available from the data repository PANGAEA (https://doi.pangaea.de/10.1594/ PANGAEA.930322, https://doi.pangaea.de/10.1594/PANGAEA.930483, https://doi. pangaea.de/10.1594/PANGAEA.930442).

\section{REFERENCES}

1. Boudreau BP, Huettel M, Forster S, Jahnke RA, McLachlan A, Middelburg JJ, et al. Permeable marine sediments: overturning an old paradigm. Eos Trans AGU. 2001;82:133-6.

2. Huettel M, Berg P, Kostka JE. Benthic exchange and biogeochemical cycling in permeable sediments. Annu Rev Mar Sci. 2014;6:23-51.

3. Huettel M, Ziebis W, Forster S. Flow-induced uptake of particulate matter in permeable sediments. Limnol Oceanogr. 1996;41:309-22.

4. Huettel M, Rusch A. Transport and degradation of phytoplankton in permeable sediment. Limnol Oceanogr. 2000;45:534-49.

5. Rusch A, Forster S, Huettel M. Bacteria, diatoms and detritus in an intertidal sandflat subject to advective transport across the water-sediment interface. Biogeochemistry. 2001;55:1-27.

6. Ahmerkamp S, Winter C, Krämer K, de Beer D, Janssen F, Friedrich J, et al. Regulation of benthic oxygen fluxes in permeable sediments of the coastal ocean. Limnol Oceanogr. 2017;62:1935-54.

7. Jahnke RA Global Synthesis. In: Liu KK, Atkinson L, Quinones R, Talaue-McManus $\mathrm{L}$, editors. Carbon and nutrient fluxes in continental margins. Ch. 16 Berlin: Springer; 2010.

8. Joiris C, Billen G, Lancelot C, Daro MH, Mommaerts JP, Bertels A, et al. A budget of carbon cycling in the Belgian coastal zone: relative roles of zooplankton, bacterioplankton and benthos in the utilization of primary production. Neth. J. Sea Res. 1982;16:260-75.

9. Jørgensen BB, Bang $M$, Blackburn TH. Anaerobic mineralization in marinesediments from the Baltic-Sea-North Sea transition. Mar Ecol Prog Ser. 1990;59:39-54

10. Middelburg JJ, Barranguet C, Boschker HTS, Herman PMJ, Moens T, Heip CHR. The fate of intertidal microphytobenthos carbon: an in situ ${ }^{13} \mathrm{C}$-labeling study. Limnol Oceanogr. 2000;45:1224-34.

11. Böer SI, Arnosti C, van Beusekom JEE, Boetius A. Temporal variations in microbial activities and carbon turnover in subtidal sandy sediments. Biogeosciences. 2009;6:1149-65.

12. Goto N, Mitamura O, Terai H. Biodegradation of photosynthetically produced extracellular organic carbon from intertidal benthic algae. J Exp Mar Biol Ecol. 2001;257:73-86

13. Rusch A, Huettel M, Reimers CE, Taghon GL, Fuller CM. Activity and distribution of bacterial populations in Middle Atlantic Bight shelf sands. FEMS Microb Ecol. 2003:44:89-100.

14. Hewson I, Vargo GA, Fuhrman JA. Bacterial diversity in shallow oligotrophic marine benthos and overlying waters: effects of virus infection, containment, and nutrient enrichment. Microb Ecol. 2003;46:322-36.

15. Teske A, Durbin A, Ziervogel K, Cox C, Arnosti C. Microbial community composition and function in permanently cold seawater and sediments from an Arctic fjord of Svalbard. Appl Environ Microbiol. 2011;77:2008-18.

16. Zinger L, Amaral-Zettler LA, Fuhrman JA, Horner-Devine MC, Huse SM, Welch DBM, et al. Global patterns of bacterial beta-diversity in seafloor and seawater ecosystems. PLoS ONE. 2011;6:e24570.

17. Cardman Z, Arnosti C, Durbin A, Ziervogel K, Cox C, Steen AD, et al. Verrucomicrobia are candidates for polysaccharide-degrading bacterioplankton in an Arctic fjord of Svalbard. Appl Environ Microbiol. 2014;80:3749-56. 
18. Teeling H, Fuchs BM, Becher D, Klockow C, Gardebrecht A, Bennke CM, et al. Substrate-controlled succession of marine bacterioplankton populations induced by a phytoplankton bloom. Science. 2012;336:608-11.

19. Teeling H, Fuchs BM, Bennke CM, Kruger K, Chafee M, Kappelmann L, et al. Recurring patterns in bacterioplankton dynamics during coastal spring algae blooms. eLife. 2016;5:e11888.

20. Fuhrman JA, Hewson I, Schwalbach MS, Steele JA, Brown MV, Naeem S. Annually reoccurring bacterial communities are predictable from ocean conditions. Proc Natl Acad Sci USA. 2006;103:13104-9.

21. Chafee $M$, Fernàndez-Guerra $A$, Buttigieg $P L$, Gerdts $G$, Eren $A M$, Teeling $H$, et al. Recurrent patterns of microdiversity in a temperate coastal marine environment. ISME J. 2018;12:237-52.

22. Mayer LM. Extracellular proteolytic enzyme activity in sediments of an intertidal mudflat. Limnol Oceanogr. 1989;34:973-81.

23. Middelburg J, Klaver G, Nieuwenhuize J, Wielemaker A, Haas W, Vlug T, et al. Organic matter mineralization in intertidal sediment along an estuarine gradient. Mar Ecol Prog Ser. 1996;132:157-68.

24. Tabuchi K, Kojima H, Fukui M. Seasonal changes in organic matter mineralization in a sublittoral sediment and temperature-driven decoupling of key processes. Microb Ecol. 2010;60:551-60.

25. Hoffmann K, Hassenrück C, Salman-Carvalho V, Holtappels M, Bienhold C. Response of bacterial communities to different detritus compositions in Arctic deep-sea sediments. Front Microbiol. 2017;8:266.

26. Gobet A, Boer SI, Huse SM, van Beusekom JEE, Quince C, Sogin ML, et al. Diversity and dynamics of rare and of resident bacterial populations in coastal sands. ISME J. 2012;6:542-53.

27. Mills $H J$, Hunter $E$, Humphrys $M$, Kerkhof $L$, McGuinness $L$, Huettel $M$, et al. Characterization of nitrifying, denitrifying, and overall bacterial communities in permeable marine sediments of the northeastern Gulf of Mexico. Appl Environ Microbiol. 2008;74:4440-53.

28. Probandt D, Knittel K, Tegetmeyer HE, Ahmerkamp S, Holtappels M, Amann R. Permeability shapes bacterial communities in sublittoral surface sediments. Environ Microbiol. 2017;19:1584-99.

29. Tait K, Airs RL, Widdicombe CE, Tarran GA, Jones MR, Widdicombe S. Dynamic responses of the benthic bacterial community at the Western English Channel observatory site L4 are driven by deposition of fresh phytodetritus. Prog Oceanogr. 2015;137:546-58.

30. Wiltshire K, Kraberg A, Bartsch I, Boersma M, Franke H-D, Freund J, et al. Helgoland Roads, North Sea: 45 years of change. Estuaries and Coasts. 2010;33:295-310.

31. Probandt D. Microbial ecology of subtidal sandy sediments [PhD thesis]. Bremen: University of Bremen; 2017.

32. Berge J, Renaud PE, Darnis G, Cottier F, Last K, Gabrielsen TM, et al. In the dark: a review of ecosystem processes during the Arctic polar night. Prog Oceanogr. 2015;139:258-71.

33. Boehnert S, Ruiz Soto S, Fox BRS, Yokoyama Y, Hebbeln D. Historic development of heavy metal contamination into the Firth of Thames, New Zealand. Geo-Mar Lett. 2020;40:149-65.

34. Lorenzen CJ. Determination of chlorophyll and pheo-pigments: spectrophotometric eqations. Limnol Oceanogr. 1967;12:343-6.

35. Zhou J, Bruns MA, Tiedje JM. DNA recovery from soils of diverse composition. Appl Environ Microbiol. 1996;62:316-22.

36. Herlemann DPR, Labrenz M, Jürgens K, Bertilsson S, Waniek JJ, Andersson AF. Transitions in bacterial communities along the $2000 \mathrm{~km}$ salinity gradient of the Baltic Sea. ISME J. 2011;5:1571-9.

37. Bushnell B, Rood J, Singer E. BBMerge-accurate paired shotgun read merging via overlap. PLoS ONE. 2017;12:e0185056.

38. Schloss PD, Westcott $S L$, Ryabin $T$, Hall JR, Hartmann $M$, Hollister $E B$, et al. Introducing mothur: open-source, platform-independent, community-supported software for describing and comparing microbial communities. Appl Environ Microbiol. 2009;75:7537-41.

39. Quast C, Pruesse E, Yilmaz P, Gerken J, Schweer T, Yarza P, et al. The SILVA ribosomal RNA gene database project: improved data processing and web-based tools. Nucleic Acids Res. 2013;41:D590-D596.

40. Callahan BJ, McMurdie PJ, Holmes SP. Exact sequence variants should replace operational taxonomic units in marker-gene data analysis. ISME J. 2017;11:2639-43.

41. Oksanen J, Blanchet F, Friendly M, Kindt R, Legendre $P$, McGlinn D, et al. vegan: Community Ecology Package. R package version. 2019;2:5-6.

42. Team R.C. R: a language and environment for statistical computing. Vienna, Austria: R Foundation for Statistical Computing. https://www.r-project.org/; 2019.

43. Wickham H, Averick M, Bryan J, Chang W, McGowan L, François R, et al. Welcome to the Tidyverse. J Open Source Softw. 2019;4:1686.

44. Chapman MG, Underwood AJ. Ecological patterns in multivariate assemblages: information and interpretation of negative values in ANOSIM tests. Mar Ecol Prog Ser. 1999;180:257-65.
45. Pernthaler A, Pernthaler J, Amann R. Fluorescence in situ hybridization and catalyzed reporter deposition for the identification of marine bacteria. Appl Environ Microbiol. 2002;68:3094-101.

46. Pernthaler J, Pernthaler A, Amann R. Automated enumeration of groups of marine picoplankton after fluorescence in situ hybridization. Appl Environ Microbiol. 2003:69:2631-7.

47. Bennke CM, Reintjes G, Schattenhofer M, Ellrott A, Wulf J, Zeder M, et al. Modification of a high-throughput automatic microbial cell enumeration system for shipboard analyses. Appl Environ Microbiol. 2016;82:3289-96.

48. Ludwig W, Strunk O, Westram R, Richter L, Meier H, Yadhukumar, et al. ARB: a software environment for sequence data. Nucleic Acids Res. 2004;32:1363-71.

49. Snaidr J, Amann R, Huber I, Ludwig W, Schleifer K, Snaidr J, et al. Phylogenetic analysis and in situ identification of bacteria in activated sludge. Appl Environ Microbiol. 1997;63:2884-96.

50. Bockelmann F-D, Puls W, Kleeberg U, Müller D, Emeis K-C. Mapping mud content and median grain-size of North Sea sediments-a geostatistical approach. Mar Geol. 2018;397:60-71.

51. Hoshino T, Doi H, Uramoto G-I, Wörmer L, Adhikari RR, Xiao N, et al. Global diversity of microbial communities in marine sediment. Proc Natl Acad Sci USA. 2020;117:27587-97.

52. Probandt D, Eickhorst T, Ellrott A, Amann R, Knittel K. Microbial life on a sand grain: from bulk sediment to single grains. ISME J. 2017;12:623.

53. Acosta-González A, Rosselló-Móra R, Marqués S. Characterization of the anaerobic microbial community in oil-polluted subtidal sediments: aromatic biodegradation potential after the Prestige oil spill. Environ Microbiol. 2013;15:77-92.

54. Tian F, Yu Y, Chen B, Li H, Yao Y-F, Guo X-K. Bacterial, archaeal and eukaryotic diversity in Arctic sediment as revealed by $16 \mathrm{~S}$ rRNA and 18S rRNA gene clone libraries analysis. Polar Biol. 2009;32:93-103.

55. Zeng Y, Zou Y, Grebmeier JM, He J, Zheng T. Culture-independent and culturedependent methods to investigate the diversity of planktonic bacteria in the northern Bering Sea. Polar Biol. 2012;35:117-29.

56. Santelli CM, Orcutt BN, Banning E, Bach W, Moyer CL, Sogin ML, et al. Abundance and diversity of microbial life in ocean crust. Nature. 2008;453:653-6.

57. Ravenschlag K, Sahm K, Pernthaler J, Amann R. High bacterial diversity in permanently cold marine sediments. Appl Environ Microbiol. 1999;65:3982-9.

58. Hunter EM, Mills HJ, Kostka JE. Microbial community diversity associated with carbon and nitrogen cycling in permeable shelf sediments. Appl Environ Microbiol. 2006;72:5689-701.

59. Dyksma S, Bischof K, Fuchs BM, Hoffmann K, Meier D, Meyerdierks A, et al. Ubiquitous Gammaproteobacteria dominate dark carbon fixation in coastal sediments. ISME J. 2016;10:1939-53.

60. Allers E, Wright JJ, Konwar KM, Howes CG, Beneze E, Hallam SJ, et al. Diversity and population structure of Marine Group A bacteria in the Northeast subarctic Pacific Ocean. ISME J. 2013;7:256-68.

61. Hodal H, Falk-Petersen S, Hop H, Kristiansen S, Reigstad M. Spring bloom dynamics in Kongsfjorden, Svalbard: nutrients, phytoplankton, protozoans and primary production. Polar Biol. 2012;35:191-203.

62. Jönsson BF, Salisbury JE, Mahadevan A. Large variability in continental shelf production of phytoplankton carbon revealed by satellite. Biogeosciences. 2011;8:1213-23.

63. Kuliński K, Kędra M, Legeżyńska J, Gluchowska M, Zaborska A. Particulate organic matter sinks and sources in high Arctic fjord. J Mar Syst. 2014;139:27-37.

64. Bourgeois S, Kerhervé P, Calleja ML, Many G, Morata N. Glacier inputs influence organic matter composition and prokaryotic distribution in a high Arctic fjord (Kongsfjorden, Svalbard). J Mar Syst. 2016;164:112-27.

65. Zaborska A, Włodarska-Kowalczuk M, Legeżyńska J, Jankowska E, Winogradow A, Deja K. Sedimentary organic matter sources, benthic consumption and burial in west Spitsbergen fjords-signs of maturing of Arctic fjordic systems? J Mar Syst. 2018;180:112-23.

66. McGovern M, Pavlov AK, Deininger A, Granskog MA, Leu E, Søreide JE, et al. Terrestrial inputs drive seasonality in organic matter and nutrient biogeochemistry in a high Arctic fjord system (Isfjorden, Svalbard). Front Mar Sci. 2020;7:747.

67. Avci B, Krüger K, Fuchs BM, Teeling H, Amann RI. Polysaccharide niche partitioning of distinct Polaribacter clades during North Sea spring algal blooms. ISME J. 2020;14:1369-83.

68. Braeckman U, Janssen F, Lavik G, Elvert M, Marchant H, Buckner $C$, et al. Carbon and nitrogen turnover in the Arctic deep sea: in situ benthic community response to diatom and coccolithophorid phytodetritus. Biogeosciences. 2018;15:6537-57.

69. Guilini K, Oevelen DV, Soetaert K, Middelburg JJ, Vanreusela A. Nutritional importance of benthic bacteria for deep-sea nematodes from the Arctic ice margin: results of an isotope tracer experi5ment. Limnol Oceanogr. 2010;55: 1977-89.

70. van Oevelen D, Soetaert K, Middelburg J, Herman P, Moodley L, Hamels I, et al. Carbon flows through a benthic food web: Integrating biomass, isotope and tracer data. J Mar Res. 2006;64:453-82. 
71. Danovaro R, Dell'Anno A, Corinaldesi C, Magagnini M, Noble R, Tamburini C. et al. Major viral impact on the functioning of benthic deep-sea ecosystems. Nature. 2008;454:1084-7.

72. Miller DC. Abrasion effects on microbes in sandy sediments. Mar Ecol Prog Ser. 1989;55:73-82.

73. Ahmerkamp S, Marchant HK, Peng C, Probandt D, Littmann S, Kuypers MM. et al. The effect of sediment grain properties and porewater flow on microbial abundance and respiration in permeable sediments. Sci. Rep. 2020;10:3573

74. Barka EA, Vatsa P, Sanchez L, Gaveau-Vaillant N, Jacquard C, Klenk HP. et al. Taxonomy, physiology, and natural products of Actinobacteria. Microbiol Mol Biol Rev. 2016;80:1-43.

75. Schrempf H. Actinobacteria within soils: capacities for mutualism, symbiosis and pathogenesis. FEMS Microbiol Lett. 2013;342:77-78.

76. Giovannoni SJ, Stingl U. Molecular diversity and ecology of microbial plankton Nature. 2005:437:343-8.

77. Yilmaz P, Iversen MH, Hankeln W, Kottmann R, Quast C, Glöckner FO. Ecological structuring of bacterial and archaeal taxa in surface ocean waters. FEMS Microbiol Ecol. 2012;81:373-85

78. Bienhold C, Zinger L, Boetius A, Ramette A. Diversity and biogeography of bathyal and abyssal seafloor bacteria. PLoS ONE. 2016;11:e0148016.

79. Rappé MS, Kemp PF, Giovannoni SJ. Phylogenetic diversity of marine coastal picoplankton 16S rRNA genes cloned from the continental shelf off Cape Hatteras, North Carolina. Limnol Oceanogr. 1997;42:811-26.

80. Zeng Y-X, Yu Y, Li H-R, Luo W. Prokaryotic community composition in Arctic Kongsfjorden and sub-arctic northern Bering Sea sediments as revealed by 454 pyrosequencing. Front Microbiol. 2017;8:2498.

81. Fang X-M, Zhang T, Li J, Wang NF, Wang Z, Yu LY. Bacterial community pattern along the sediment seafloor of the Arctic fjorden (Kongsfjorden, Svalbard). Antonie Van Leeuwenhoek. 2019;112:1121-36.

82. Ziemert N, Lechner A, Wietz M, Millán-Aguiñaga N, Chavarria KL, Jensen PR. et al. Diversity and evolution of secondary metabolism in the marine actinomycete genus salinispora. Proc Natl Acad Sci USA. 2014;111:e1130-1139.

83. Manivasagan $\mathrm{P}$, Venkatesan J, Sivakumar K, Kim SK. Pharmaceutically active secondary metabolites of marine actinobacteria. Microbiol Res. 2014;169:262-78.

84. Kamjam M, Sivalingam P, Deng Z, Hong K. Deep sea Actinomycetes and their secondary metabolites. Front Microbiol. 2017;8:760.

85. Lewin GR, Carlos C, Chevrette MG, Horn HA, McDonald BR, Stankey RJ. et al. Evolution and ecology of Actinobacteria and their bioenergy applications. Annu Rev Microbiol. 2016;70:235-54.

86. Matsumoto A, Kasai H, Matsuo Y, Ōmura S, Shizuri Y, Takahashi Y. llumatobacter fluminis gen. nov., sp. nov., a novel actinobacterium isolated from the sediment of an estuary. J Gen Appl Microbiol. 2009;55:201-5.

87. Ghai R, Mizuno CM, Picazo A, Camacho A, Rodriguez-Valera F. Metagenomics uncovers a new group of low GC and ultra-small marine Actinobacteria. Sci Rep. 2013;3:2471.

88. El Kaoutari A, Armougom F, Gordon J, Raoult D, Henrissat B. The abundance and variety of carbohydrate-active enzymes in the human gut microbiota. Nat Rev Microbiol. 2013;11:497-504.

89. Berlemont R, Martiny AC. Glycoside hydrolases across environmental microbial communities. PLoS Comp. Biol. 2016;12:e1005300.

90. Becker S, Tebben J, Coffinet S, Wiltshire K, Iversen MH, Harder T, et al. Laminarin is a major molecule in the marine carbon cycle. Proc Natl Acad Sci USA. 2020;117:6599-607.

91. Coutinho MCL, Teixeira VL, Santos CSG. A review of "Polychaeta" chemicals and their possible ecological role. J Chem Ecol. 2018;44:72-94.

92. Arnosti C. Functional differences between Arctic seawater and sedimentary microbial communities: contrasts in microbial hydrolysis of complex substrates. FEMS Microbiol Ecol. 2008;66:343-51.

93. Krüger K, Chafee M, Francis TB, Del Rio TG, Becher D, Schweder T, et al. In marine Bacteroidetes the bulk of glycan degradation during algae blooms is mediated by few clades using a restricted set of genes. ISME J. 2019;13: 2800-16.

94. Reintjes G, Arnosti C, Fuchs BM, Amann R. An alternative polysaccharide uptake mechanism of marine bacteria. ISME J. 2017;11:1640-50.
95. Arnosti C, Jørgensen BB. High activity and low temperature optima of extracellular enzymes in Arctic sediments: implications for carbon cycling by heterotrophic microbial communities. Mar Ecol Prog Ser. 2003;249: 15-24.

96. Arnosti C, Jørgensen BB. Organic carbon degradation in Arctic marine sediments, Svalbard: a comparison of initial and terminal steps. Geomicrobiol J. 2006;23: $551-63$.

\section{ACKNOWLEDGEMENTS}

We acknowledge Christoph Walcher, Markus Brand, Madlen Friedrich and team for sampling at Helgoland (Centre for Scientific Diving) and Antje Wichels and Eva-Maria Brodte for providing infrastructure at Alfred Wegener Institute Helgoland. We thank Karen Wiltshire for providing metadata for Helgoland Roads. The captain and crew of R/V Farm are acknowledged for great support and Alexander Michaud for enabling sampling in Svalbard. We are grateful to Carol Arnosti for valuable comments on the manuscript and inspiring discussions and to Christiane Hassenrück for support with ASV analysis. We acknowledge Kathrin Büttner, Jörg Wulf, and Martina Alisch for excellent technical assistance, and Jannika Moye, Jan Brüwer, Meike Knittel, Erich Nordmann, Max Holthuis, and Stuart Thomson for sampling and logistical support. This work was funded by the Max Planck Society. JT received funding from the Cluster of Excellence "The Ocean Floor-Earth's Uncharted Interface" (Germany's Excellence Strategy-EXC-2077-390741603 of the DFG) and MAJ from Svalbard Environmental Protection Fund grant number 16/105.

\section{FUNDING}

Open Access funding enabled and organized by Projekt DEAL.

\section{COMPETING INTERESTS}

The authors declare no competing interests.

\section{ADDITIONAL INFORMATION}

Supplementary information The online version contains supplementary material available at https://doi.org/10.1038/s43705-021-00028-w.

Correspondence and requests for materials should be addressed to K.K.

Reprints and permission information is available at http://www.nature.com/ reprints

Publisher's note Springer Nature remains neutral with regard to jurisdictional claims in published maps and institutional affiliations.

Attribution 4.0 International License, which permits use, sharing, adaptation, distribution and reproduction in any medium or format, as long as you give appropriate credit to the original author(s) and the source, provide a link to the Creative Commons license, and indicate if changes were made. The images or other third party material in this article are included in the article's Creative Commons license, unless indicated otherwise in a credit line to the material. If material is not included in the article's Creative Commons license and your intended use is not permitted by statutory regulation or exceeds the permitted use, you will need to obtain permission directly from the copyright holder. To view a copy of this license, visit http://creativecommons. org/licenses/by/4.0/.

(c) The Author(s) 2021 